\title{
Molecular Aspects of the Reactivation Process of Acetylcholinesterase Inhibited by Cyclosarin
}

\author{
Karina S. Matos, ${ }^{a}$ Daiana T. Mancini, ${ }^{a}$ Elaine F. F. da Cunha, ${ }^{a}$ Kamil Kuča, ${ }^{b, c}$ \\ Tanos C. C. França ${ }^{*, d}$ and Teodorico C. Ramalho*,a \\ ${ }^{a}$ Chemistry Department, Federal University of Lavras, Lavras-MG, Brazil \\ ${ }^{b}$ Department of Toxicology, Faculty of Military Health Sciences UO, University of Defence, Czech Republic \\ 'University Hospital Hradec Králové, Sokolská 581, 50005 Hradec Králové, Czech Republic \\ ${ }^{d}$ Laboratory of Molecular Modeling Applied to the Chemical and Biological Defense (LMCBD), \\ Military Institute of Engineering, Rio de Janeiro-RJ, Brazil
}

\begin{abstract}
No presente trabalho foi aplicada uma metodologia teórica desenvolvida em um trabalho anterior que utiliza os programas Molegro ${ }^{\circledR}$ e Spartan ${ }^{\circledR}$ para avaliar as constantes cinéticas de associação e reativação de oximas, em relação a resultados in vitro previamente reportados na literatura. Como observado antes, os resultados mostraram boa correlação entre as energias livres teóricas de ligação das oximas e os dados experimentais, corroborando a metodologia como adequada para a predição de parâmetros cinéticos e termodinâmicos, os quais podem ser úteis para o planejamento e seleção de novas e mais efetivas oximas.
\end{abstract}

In this work we applied a theoretical methodology developed in a former work, using the Molegro ${ }^{\circledR}$ and Spartan ${ }^{\circledast}$ softwares, to evaluate the association and kinetic reactivation constants of oximes, facing in vitro data previously reported in the literature. As reported before, results showed a good agreement between the theoretical binding free energies of the oximes and experimental data, corroborating the methodology as suitable for the prediction of kinetic and thermodynamic parameters that might be helpful for the design and selection of new and more effective oximes. agents

Keywords: acetylcholinesterase, QM/MM, chemical mechanism of reactivation, neurotoxic

\section{Introduction}

The action of the nerve agents ${ }^{1,2}$ as inhibitors of the enzyme acetylcholinesterase (AChE) stops the hydrolysis of the neurotransmitter acetylcholine and can lead to an irreversible inhibition of this enzyme (aging) thus triggering the cholinergic syndrome. ${ }^{3}$ To avoid this it's necessary a nucleophile, like an oxime, whose hydroxyl group is believed to be able to remove the nerve agent from the active site and reactivate $\mathrm{AChE}$ (Scheme 1). This reactivation reaction (illustrated in equation 1) involves, first, the association of the oxime to the inhibited enzyme (EIOx) and then the reactivation of the enzyme by the leaving of the oxime complexed to the neurotoxic agent (I-Ox) ${ }^{4,5}$

*e-mail: tanos@ime.eb.br, teo@dqi.ufla.br
$\mathrm{EI}+\mathrm{Ox} \stackrel{\mathrm{K}_{\mathrm{R}}}{\rightleftharpoons} \mathrm{EIOx} \stackrel{\mathrm{k}_{\mathrm{r}}}{\longrightarrow} \mathrm{E}+\mathrm{I}-\mathrm{Ox}$

Where $\mathrm{K}_{\mathrm{R}}$ and $\mathrm{k}_{\mathrm{r}}$ are the dissociation constants, which represent the affinity of oximes for the inhibited AChE, and the rate constant for the decomposition of the stable enzyme-inhibitor-reactivator complex, respectively. ${ }^{4,5}$

The literature reports many structurally different oximes able to perform the reactivation of AChE inhibited by several different nerve agents, but one structure able to act efficiently against all the existing neurotoxic agents has not yet been reported $\mathrm{d}^{4,5}$ and oximes that are efficient against one specific nerve agent can be completely ineffective with another. ${ }^{2-6}$ Several molecular modelling studies available in literature point out to important features on the oximes structures that could be very useful to guide experimental research on this issue. ${ }^{7-19}$ In a former work ${ }^{4}$ we have 

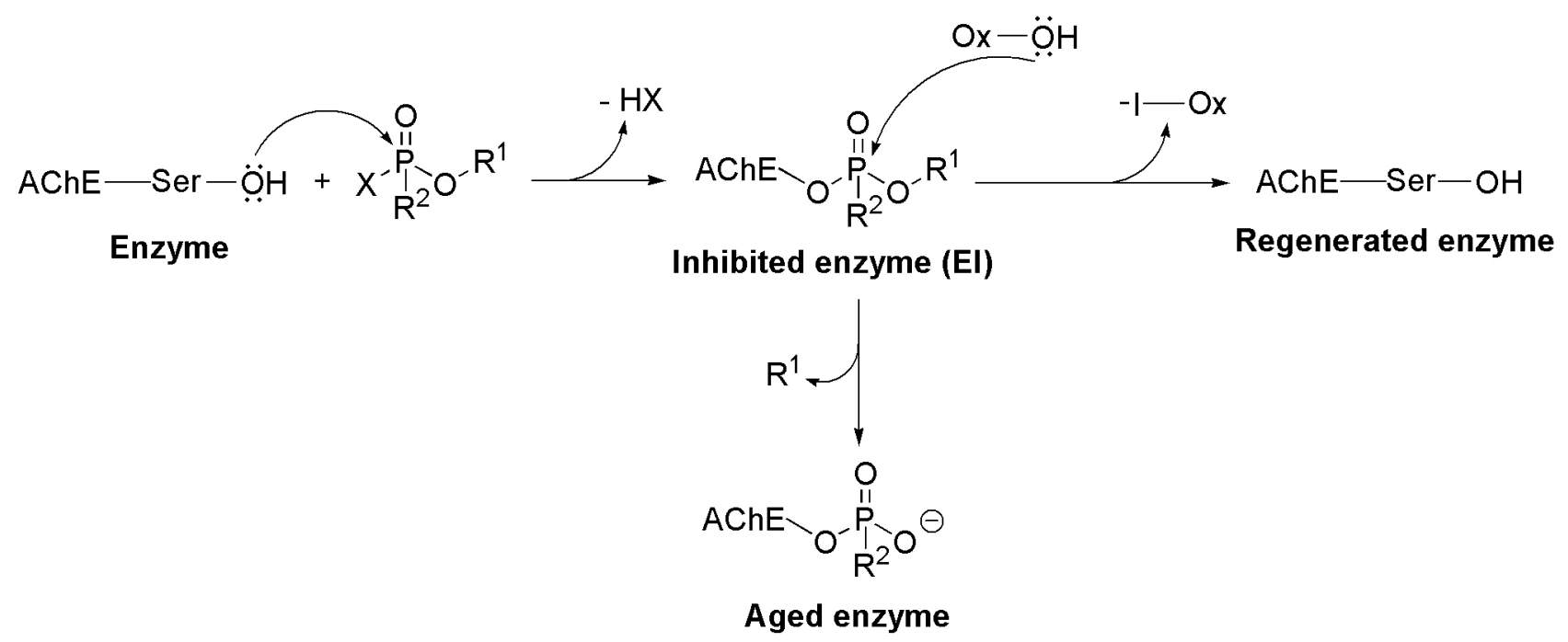

Scheme 1. Inhibition, desinhibition and aging of AChE. $\mathrm{X}$ is the leaving group.

contributed to some degree to this kind of work, employing docking studies and DFT calculations for evaluation of $\mathrm{K}_{\mathrm{R}}$ and $\mathrm{k}_{\mathrm{r}}$ of oximes in Mus musculus AChE (MmAChE) inhibited by tabun, using Molegro ${ }^{\circledR}$ Virtual Docker 2006 (MVD), ${ }^{20}$ Spartan $08^{\circledast, 21}$ and Gaussian $98^{\circledR, 22}$ softwares. Here we applied the same methodology to evaluate these constants in a new set of oximes for MmAChE inhibited by the nerve agent cyclosarin. Our results corroborated this methodology as suitable for the prediction of kinetic and thermodynamic parameters for oximes that might be helpful for the design and selection of new and more effective oximes.

\section{Methodology}

\section{Ligands data set and docking energy calculations}

The in vitro data of $\mathrm{K}_{\mathrm{R}}$ and $\mathrm{k}_{\mathrm{r}}$ for the oximes studied in this work (Figure 1) regarding AChE inhibited by cyclosarin, were reported by Kassa et al. ${ }^{5}$ Crystallographic coordinates of $\mathrm{MmAChE}$ phosphonylated by sarin and complexed with the oxime HI-6 (PDB code: 2WHP) ${ }^{23}$ were taken from the Brookhaven Protein Data Bank ${ }^{23}$ and had the crystallographic water molecules removed in the SPDBViewer software ${ }^{24}$ for the best performance of the calculations due to the existence of hydrophobic areas distinct from the binding site inside AChE. ${ }^{25}$ The sarin structure inside the crystallographic structure of $\mathrm{MmAChE}$ was completed through the insertion of the group $-\mathrm{CH}_{2} \mathrm{CH}_{2} \mathrm{CH}_{2}-$ using the software Spartan08 ${ }^{\circledR, 21}$ (MMFF94 force field) in order to afford the 3D structure of $\mathrm{MmAChE}$ phosphonylated by cyclosarin. The 3D structures of each inhibitor were built based on the bioactive conformation of HI-6 inside this structure, and subsequently, the overall geometry optimizations and partial atomic charge distribution calculations were performed with the same program using the AM1 semi-empirical molecular orbital method. ${ }^{22}$ These QM electrostatic charges were incorporated in the AMBER force field in order to evaluate coulomb interactions in the docking procedure.

In the same way as before,,$^{4}$ the compounds were docked into the $M m A C h E$ binding site using $\mathrm{MVD}^{\circledR}$, a program for predicting the most likely conformation of how a ligand will bind to a macromolecule. The MolDock scoring function (MolDock score) used by MVD ${ }^{\circledR}$ is derived from the PLP (piecewise linear potential) and further extended in GEMDOCK (generic evolutionary method for molecular DOCK) with a new hydrogen bonding term and new charge schemes. ${ }^{20}$ The docking search algorithm used in $\mathrm{MVD}^{\circledR}$ is based on interactive optimization techniques inspired by the Darwinian evolution theory (evolutionary algorithms-EA). Binding sites were restricted within spheres with radius from 10 to $15 \AA$, according to the ligand size, centered at the HI- 6 binding site in the protein complex and enclosing all the active site residues. Ligand molecules and a subset region composed of all amino acid residues (side chain) having at least one atom within $12 \AA$ of the center of the HI-6 were considered flexible during the docking simulation. Due to the stochastic nature of the ligand-protein docking search algorithm, about 10 runs were conducted and 30 docking solutions were retained for each ligand. The best superimposing poses related to HI-6 were chosen for the analysis performed in this work.

\section{DFT studies}

From the selected structures with the docking procedure, QM/MM techniques were performed to determine the 
<smiles>NC(=O)c1ccc[n+](COC[n+]2ccccc2/C=N/O)c1/C=N/O</smiles><smiles>NC(=O)c1cc[n+](COC[n+]2ccc(/C=N/O)cc2/C=N/O)cc1</smiles><smiles>OCCOCCOCCOC[n+]1ccc(/C=N/O)cc1</smiles><smiles>O/N=C\c1cccc[n+]1CCCC[n+]1ccccc1/C=N\O</smiles>

Figure 1. Structures of the oximes studied.

preferred route for the reactivation process, combining docking techniques and DFT calculations at the QM/MM interface for the enzymatic mechanism. The QM/MM approach seeks to partition the target system under study into $\mathrm{QM}$ and $\mathrm{MM}$ regions. On the technical side, we have applied a procedure combining docking techniques and DFT calculations at the QM/MM interface for the enzymatic mechanism. The hydrogen is employed as the link atom to saturate the free valency, so that the electronic effects resulting from $\mathrm{QM} / \mathrm{MM}$ partitioning are minimized. The current research utilized the ONIOM methodology. ${ }^{26}$ All classical molecular mechanics (MM) calculations have been performed with AMBER all-atom force field. ${ }^{27,28}$ The QM calculations were carried out in the Spartan $08^{\oplus 21}$ and Gaussian $98^{\oplus 22}$ packages. The QM regions were cut out from the docking results in the SPDBViewer software ${ }^{24}$ and consisted of residues, neighboring peptide bonds, link atoms, crystallographic water molecules, ligand and cyclosarin inside a sphere with radius of $15 \AA$, centered at each oxime.

The initial coordinates for the heavy atoms were taken from the crystal structure. All the transition states, intermediates and precursors involved were calculated. Each conformer was fully optimized at the DFT level with B3LYP/6-31G(d,p) ${ }^{29,30}$ Furthermore, after each optimization, a force constant calculation was made in order to verify whether the optimized structures were indeed local minima (no imaginary frequencies) or transition states (one imaginary frequency).

\section{Results and Discussion}

\section{Docking results}

After docked inside the $\mathrm{MmAChE}$ active site, the oximes (Figure 1) had all their reasonable binding orientations for the $M m A C h E$ reactivation investigated, according to a search of the conformational space for different ligand orientations performed by MVD ${ }^{\circledR} .{ }^{20}$ As mentioned before the water molecules were removed to perform the calculations due to the hydrophobic site for the alkoxy leaving group of the substrate, including residues Trp86(84), Tyr337(330), and Phe338(331), which are among the key elements maintaining the functional architecture of the active center, contributing to the stabilization of the Michaelis-Menten complexes. ${ }^{31}$ The low-energy interaction modes were, then, chosen for further minimizations. ${ }^{4}$ From the molecular docking simulations performed between each studied compound and the enzyme, the binding modes with the lowest docked energies were selected. ${ }^{4}$

Our findings suggest that the correlation between theoretical and experimental data is satisfactory. The identification of low-energy conformation is an important step in the understanding of the relationship between structure and biological activity of a molecule. It should be kept in mind, however, that derived data on the bioactive conformation from experimental results should serve as verification wherever possible ${ }^{32,33}$ 
As shown in Table 1, the oxime with the most promising in vitro data was K005. The favorable orientation of this oxime inside the $\mathrm{MmAChE}$ active site involves five hydrogen bonds, with the residues Tyr124, Trp286, Phe295, Arg 296 and Phe338 respectively. Besides, the oxime with the least favorable in vitro data (BI-6) was able to perform only 2 hydrogen bonds (with the residues Tyr124 and Glu285).

Table 1 presents the predicted dissociation free energies of the oximes with $\mathrm{AChE}$ and the experimental values reported by Kassa et al., 5 in the same way as demonstrated before for $\mathrm{MmAChE},{ }^{4}$ thus confirming our former findings that we can give a more quantitative explanation to the structure-activity relationship of the inhibitory mechanism for these inhibitors based on the binding free energies and their correlation with $\mathrm{K}_{\mathrm{R}}$ of the inhibited enzyme-reactivator complexes. $^{4}$

Table 1. Energy values for $M m A C h E$ reactivators in the active site and dissociation constants of the inhibited MmAChE-reactivator complex

\begin{tabular}{|c|c|c|c|c|c|}
\hline ligand & $\begin{array}{c}\mathrm{pK}_{\mathrm{R}} * / \\
\left(\mu \mathrm{mol} \mathrm{L} \mathrm{L}^{-1}\right)\end{array}$ & $\begin{array}{c}\Delta \mathrm{E}^{* *} / \\
\left(\mathrm{kcal} \mathrm{mol}^{-1}\right)\end{array}$ & residue & $\begin{array}{c}\text { strength } \\
\text { bond / } \\
\left(\mathrm{kcal} \mathrm{mol}^{-1}\right)\end{array}$ & $\begin{array}{c}\text { dist. / } \\
\AA\end{array}$ \\
\hline \multirow{5}{*}{ K005 } & \multirow{5}{*}{5.30} & \multirow{5}{*}{-143.48} & Phe338 & -0.68 & 3.46 \\
\hline & & & Phe295 & -2.16 & 3.17 \\
\hline & & & Tyr124 & -1.35 & 3.33 \\
\hline & & & Arg296 & -2.50 & 2.72 \\
\hline & & & Trp286 & -0.95 & 2.75 \\
\hline \multirow{6}{*}{ HI-6 } & \multirow{6}{*}{4.92} & \multirow{6}{*}{-142.98} & Tyr124 & -1.90 & 3.22 \\
\hline & & & Tyr124 & -2.50 & 2.79 \\
\hline & & & Tyr124 & -2.50 & 2.87 \\
\hline & & & Tyr124 & -1.32 & 3.33 \\
\hline & & & Ser298 & -2.50 & 2.97 \\
\hline & & & Ser298 & -2.50 & 3.10 \\
\hline \multirow{8}{*}{ methoxime } & \multirow{8}{*}{4.82} & \multirow{8}{*}{-142.32} & Thr83 & -0.69 & 3.46 \\
\hline & & & Tyr337 & -2.50 & 2.97 \\
\hline & & & Tyr337 & -2.16 & 3.17 \\
\hline & & & Tyr341 & -2.50 & 2.61 \\
\hline & & & Tyr124 & -2.50 & 2.95 \\
\hline & & & Tyr124 & -1.53 & 3.29 \\
\hline & & & Ser298 & -2.33 & 3.13 \\
\hline & & & Ser298 & -1.49 & 3.30 \\
\hline \multirow{6}{*}{ K033 } & \multirow{6}{*}{4.70} & \multirow{6}{*}{-142.86} & Trp286 & -0.11 & 3.56 \\
\hline & & & Arg296 & -2.50 & 2.82 \\
\hline & & & Arg296 & -2.50 & 3.01 \\
\hline & & & Phe295 & -0.52 & 3.05 \\
\hline & & & Tyr124 & -1.22 & 3.35 \\
\hline & & & Tyr124 & -0.50 & 3.50 \\
\hline \multirow{3}{*}{ HS-6 } & \multirow{3}{*}{4.35} & \multirow{3}{*}{-142.67} & Tyr124 & -2.50 & 2.80 \\
\hline & & & Tyr124 & -2.50 & 3.09 \\
\hline & & & Phe295 & -2.50 & 3.08 \\
\hline \multirow{5}{*}{ HLö-7 } & \multirow{5}{*}{3.00} & \multirow{5}{*}{-141.91} & Arg296 & -1.33 & 3.34 \\
\hline & & & Tyr124 & -2.50 & 2.72 \\
\hline & & & Tyr124 & -2.50 & 3.09 \\
\hline & & & Tyr124 & -2.50 & 2.83 \\
\hline & & & Tyr124 & -2.46 & 3.11 \\
\hline \multirow{2}{*}{ BI-6 } & \multirow{2}{*}{1.00} & \multirow{2}{*}{-140.21} & Glu285 & -2.28 & 3.14 \\
\hline & & & Tyr124 & -1.30 & 3.34 \\
\hline
\end{tabular}

*Experimental data; $* *$ theoretical data.

\section{Mechanistic studies}

The design of new and more selective reactivation agents depends on the understanding of the oxime reactivation process mechanism. Also the dynamic effects on both, the reaction mechanism and ligand orientation should be kept in mind. The mechanism goes through an addition-elimination pathway. ${ }^{4}$ This QM/MM study is a first step in understanding the interaction between cyclosarin inhibited $\mathrm{MmAChE}$ and reactivators in a theoretical way.

Table 2 presents the kinetic parameters and $\Delta \Delta \mathrm{E}^{\#}$ predicted by theoretical calculations of the oximes and the experimental values reported by Kassa et al. ${ }^{5}$ However, in our present study, we have compared the $\Delta \mathrm{E}$ values between the transition state and the initial system for each oxime. In this way, we have obtained the tendency of reactivity of oximes, avoiding thus the direct computation of the absolute energy values. The correlation among these values is better expressed in the plot of Figure 2 and demonstrates that the kinetic parameters and the experimental values are reasonable, in the same way as demonstrated before. ${ }^{4}$ In fact, a deeper analysis of our findings shows that just methoxime does not follow the experimental tendency. We believe that a different conformation of methoxime in the AChE active site is due to a shorter carbon chain between aromatic rings. As mentioned, a good agreement between the calculated and experimental geometries for the ligands was observed from our calculations. After the optimization of the selected conformers, a force constant calculation was carried out to assure that the structures reported in Table 2 are all transition states. Thus, we have used the same computational procedure previously employed successfully for tabun-inhibited $M m \mathrm{AChE}^{4}$ and on similar systems. ${ }^{29,30}$ Again an extra stabilization of the transition state was observed through long-range interactions, such as cation- $\pi, \pi-\pi$ staking or electrostatic interactions, this time with the residues Tyr124, Glu285, Trp286, Phe295, Arg296 and Ser298.

Table 2. Relative activation energies of the transition states and kinetic parameters

\begin{tabular}{lccc}
\hline ligand & $\begin{array}{c}\mathrm{k}_{\mathrm{r}}{ }^{\mathrm{a}} / \\
\mathrm{min}^{-1}\end{array}$ & $\begin{array}{c}\Delta \Delta \mathrm{E}^{\# \mathrm{~b}} / \\
\left(\mathrm{kcal} \mathrm{mol}^{-1}\right)\end{array}$ & $\begin{array}{c}\text { frequency / } \\
\mathrm{cm}^{-1}\end{array}$ \\
\hline HI-6 & 0.350 & 220.85 & $\mathrm{i} 5.15$ \\
BI-6 & 0.150 & 170.43 & $\mathrm{i} 64.21$ \\
methoxime & 0.240 & 132.00 & $\mathrm{i} 16.59$ \\
HS-6 & 0.156 & 131.12 & $\mathrm{i} 13.68$ \\
K033 & 0.095 & 82.34 & $\mathrm{i} 5.21$ \\
K005 & 0.010 & 31.96 & $\mathrm{i} 74.20$ \\
HLö-7 & 0.008 & 0.00 & $\mathrm{i} 2.31$ \\
\hline
\end{tabular}

${ }^{\mathrm{a}}$ Rate constants of reactivation; ${ }^{5} \mathrm{~b} \Delta \Delta \mathrm{E}^{\#}=\mathrm{E}_{\mathrm{LIGi}}-\mathrm{E}_{\mathrm{HLö}-7}$. 


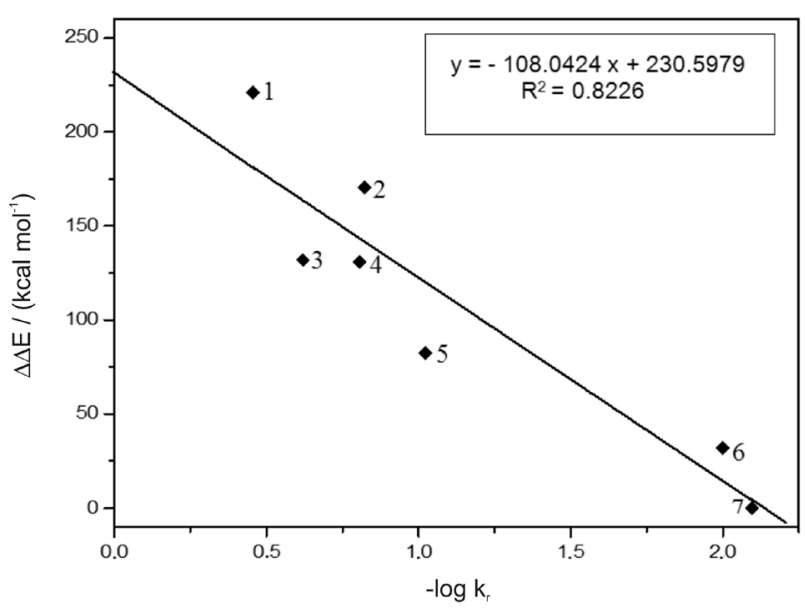

Figure 2. Plot of $-\log \mathrm{k}_{\mathrm{r}} \times \Delta \Delta \mathrm{E}^{\#}$ for the oximes studied. $1=\mathrm{HI}-6,2=\mathrm{BI}-6$, $3=$ methoxime, 4 = HS-6, 5 = K033, 6 = K005, 7 = HLö-7.

We believe that, here, the stabilization of the transition state is favored by hydrogen bonding with the closest amino acids residues: Tyr124, Trp286, Phe295, Arg296 and Phe338 which orient the oxime toward the adequate TS geometry. In that conformation (Figure 3), the oxime interacts more strongly with cyclosarin. Furthermore, the long-range interactions among the oximes and the other amino acids could also take place, such as the cation- $\pi$ interactions with Phe295, Tyr337, Phe338 and Tyr341; electrostatic interactions with Glu285 and a $\pi$ - $\pi$ staking interaction among the oxime's pyridinium ring, Tyr124 and Trp286 (see Figure 4), which occurs in the transition state geometry. Thus, our theoretical data point out that the oximes K005 and HLÖ-7 could be promising cyclosarin inhibited-AChE reactivators. K005 is considered one of the best reactivators of cyclosarin-inhibited $\mathrm{AChE}$ and shows good $K_{R}$ results (Table 1) and a high affinity for the intact enzyme (like HLö-7) showing, consequently, a high

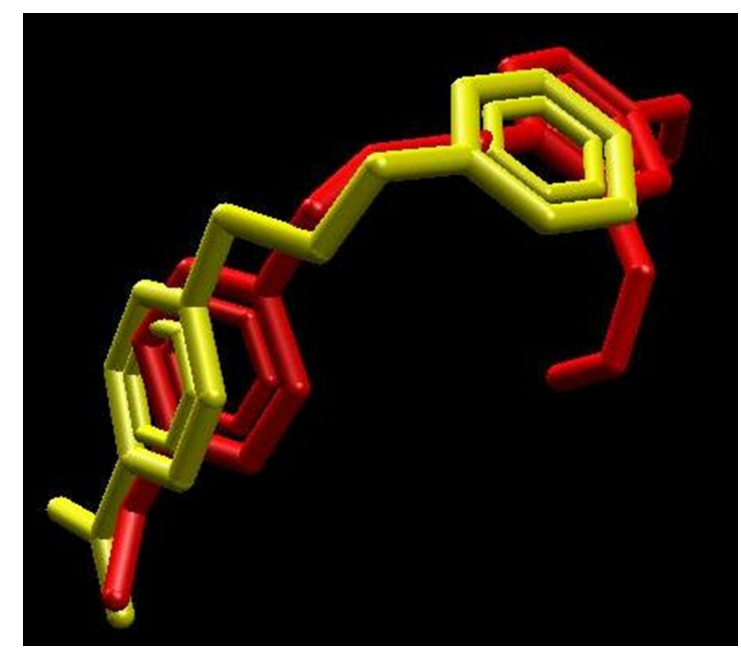

Figure 3. Superimpositions of the best conformation of HLö-7 and the structure of HI-6 from the crystal structure (PDB code 2WHP).

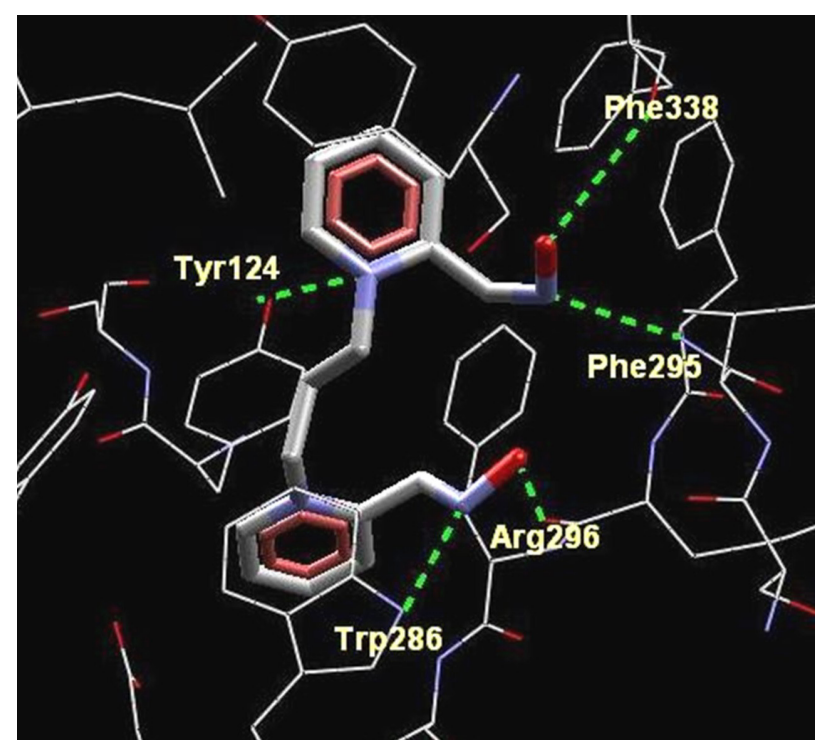

Figure 4. Hydrogen bonds formed between K005 and residues of the active site of $\mathrm{MmAChE}$.

reactivity with the enzyme (Table 2). However, the excess of those oximes can also inhibit the reactivated enzyme. ${ }^{4,5}$

\section{Conclusions}

Our results again showed good agreement between the theoretical dissociation free energies of the oximes and experimental data, corroborating the methodology used for the prediction of kinetic and thermodynamic parameters that might be helpful for the design of new $\mathrm{AChE}$ reactivators. Our findings suggest that the binding process of oximes in $\mathrm{MmAChE}$ is favorable through the amino acids residues Tyr124, Trp286, Phe295 and Arg296. We observed again that the number of hydrogen bonds with Tyr124 is a key feature to determine the oxime binding mode. Regarding the reaction pathway, we noticed that the amino acid residues Tyr124, Trp286 and Arg296 are responsible for the transition state stabilization. Finally, the results obtained here corroborate deeply with our previous study, ${ }^{4}$ reinforcing the idea that the calculated kinetic parameters might be helpful for the design and selection of new and more effective oximes.

\section{Acknowledgments}

The authors are grateful to Fundação de Amparo a Pesquisa do Estado de Minas Gerais (FAPEMIG) (T. C. R. and E. F. F. C.), Coordenação de Aperfeiçoamento de Pessoal de Nível Superior (CAPES) (D. T. M., K. S. M. and T. C. C. F.), Fundação de Amparo ao Ensino e Pesquisa do Estado do Rio de Janeiro (FAPERJ) (T. C. C. F.) and Conselho Nacional de Desenvolvimento Científico e 
Tecnológico (CNPq) (T. C. R. and E. F. F. C.) for financial support. We also would like to thank the Centro Nacional de Processamento de Alto Desempenho em São Paulo (CENAPAD-SP) for the computational facilities. This study was also supported by Project No. FVZ0000604 (K. K.).

\section{References}

1. Kryger, G.; Harel, M.; Giles, K.; Toker, L.; Velan, B.; Lazar, A.; Kronman, C.; Barak, D.; Ariel, N.; Shafferman, A.; Silman, I.; Sussman, J. L.; Acta Crystallogr., Sect. D: Biol. Crystallogr. 2000, 56, 1385.

2. Somani, S. M.; Solana, R. P.; Dube, S. N.; Chemical Warfare Agents; 1992, Academic Press: San Diego, 1992.

3. Black, R. M.; Harrison, J. M. In The Chemistry of Organophosphorus Compounds; Hartley, F. R., ed.; vol 4, Wiley \& Sons: Chichester, 1996, pp 781-840.

4. Ramalho, T. C; França, T. C. C.; Rennó, M. N.; Guimarães, A. P.; Cunha, E. F. F.; Kuča, K.; Chem. Biol. Interact. 2010, 185, 73.

5. Kassa, J.; Kuca, K.; Bartosova, L.; Kunesova, G.; Curr. Org. Chem. 2007, 11, 267.

6. Sidell, F. R.; Takafuji, E. T.; Franz, D. R.; Textbook of Military Medicine; Office of the Surgeon General: Washington D. C., 1997, p. 129.

7. Delfino, R. T.; Ribeiro, T. S.; Figueroa-Villar, J. D.; J. Braz. Chem. Soc. 2009, 20, 407.

8. Wong, L.; Radic, Z.; Brüggemann, R. J. M.; Hosea, N.; Berman, H. A.; Taylor, P.; Biochemistry 2000, 39, 5750.

9. Ekström, F.; Yuan-Ping, P.; Boman, M.; Artursson, E.; Akfur, C.; Börjegren, S.; Biochem. Pharmacol. 2006, 72, 597.

10. Ashani, Y.; Radic, Z.; Tsigelny, I.; Vellom, D. C.; Pickering, N. A.; Quinn, D. M.; Doctor, B. P.; Taylor, P.; J. Biol. Chem. 1995, 11,6370 .

11. Ekström, F. J.; Astot, C.; Pang, Y. P.; Clin. Pharmacol. Ther. 2007, 82, 282.

12. Worek, F.; Aurbek, N.; Koller, M.; Becker, C.; Eyer, P.; Thiermann, H.; Biochem. Pharmacol. 2007, 73, 1807.

13. Delfino, R. T.; Figueroa-Villar, J. D.; J. Phys. Chem. B 2009, 113,8402 .

14. Gonçalves, A. S.; França, T. C. C.; Wilter, A.; Figueroa-Villar, J. D.; J. Braz. Chem. Soc. 2006, 17, 968.

15. Gonçalves, A. S.; França, T. C. C.; Figueroa-Villar, J. D.; Pascutti, P. G.; J. Braz. Chem. Soc. 2010, 21, 179.

16. Gonçalves, A. S.; França, T. C. C.; Figueroa-Villar, J. D.; Pascutti, P. G.; J. Braz. Chem. Soc. 2011, 22, 155.

17. Steven, S. Z.; Peterson, M. W.; Hamza, A.; Zhan, C. G.; Cerasoli. D. M.; Chang, W. E.; J. Mol. Model. 2011, 17, 97.

18. Nemukhim, A. V.; Lushchekina, S. V.; Bochenkova, A. V.; Golubeva, A. A.; Varfolomeev, S. D.; J. Mol. Model. 2008, 14, 409.
19. Bernard, P. P.; Kireev, D. B.; Pintore, M.; Chrétien, J. R.; Fortier, P. L.; Froment, D.; J. Mol. Model. 2000, 6, 618.

20. Thomsen, R.; Christensen, M. H.; J. Med. Chem. 2006, 49, 3315.

21. Hehre, W. J.; Deppmeier, B. J.; Klunzinger, P. E.; PC SPARTAN Pro, Wavefunction, Inc., Irvine, CA, 1999.

22. Frisch, M. J.; Trucks, G. W.; Schlegel, H. B.; Scuseria, G. E.; Robb, M. A.; Cheeseman, J. R.; Montgomery, J. A.; Vreven, T.; Kudin, K. N.; Burant, J. C.; Millam, J. M.; Iyengar, S. S.; Tomasi, J.; Barone, V.; Mennucci, B.; Cossi, M.; Scalmani, G.; Rega, N.; Petersson, G. A.; Nakatsuji, H.; Hada, M.; Ehara, M.; Toyota, K.; Fukuda, R.; Hasegawa, J.; Ishida, M.; Nakajima, T.; Honda, Y.; Kitao, O.; Nakai, H.; Klene, M.; Li, X.; Knox, J. E.; Hratchian, H. P.; Cross, J. B.; Bakken, V.; Adamo, C.; Jaramillo, J.; Gomperts, R.; Stratmann, R. E.; Yazyev, O.; Austin, A. J.; Cammi, R.; Pomelli, C.; Ochterski, J. W.; Ayala, P. Y.; Morokuma, K.; Voth, G. A.; Salvador, P.; Dannenberg, J. J.; Zakrzewski, V. G.; Dapprich, S.; Daniels, A. D.; Strain, M. C.; Farkas, O.; Malick, D. K.; Rabuck, A. D.; Raghavachari, K.; Foresman, J. B.; Ortiz, J. V.; Cui, Q.; Baboul, A. G.; Clifford, S.; Cioslowski, J.; Stefanov, B. B.; Liu, G.; Liashenko, A.; Piskorz, P.; Komaromi, I.; Martin, R. L.; Fox, D. J.; Keith, T.; Al-Laham, M. A.; Peng, C. Y.; Nanayakkara, A.; Challacombe, M.; Gill, P. M. W.; Johnson, B.; Chen, W.; Wong, M. W.; Gonzalez, C.; Pople, J. A.; Gaussian 03, Gaussian, Inc., Wallingford, CT, 2004.

23. Ekström, F.; Hörnberg, A.; Artursson, E.; Hammarström, L.; Schneider, G.; Pang, Y.; PloS ONE 2009, 4, e5957.

24. Guex, N.; Peitsch, M. C.; Electrophoresis 1997, 18, 2714.

25. Dvir, H.; Silman, I.; Harel, M.; Rosenberry, T. L.; Sussman, J. L.; Chem-Biol. Interact. 2010, 187, 10.

26. Maseras, F. and Morokuma, K.; J. Comput. Chem. 1995, 16, 1170.

27. Cornell, W. D.; Cieplak, P.; Bayly, C. I.; Gould, I. R.; Merz, K. M.; Ferguson, D. M.; Spellmeyer, D. C.; Fox, T.; Caldwell, J. W.; Kollman. P. A.; J. Am. Chem. Soc. 1995, 117, 5179.

28. Jorgensen,W. L.; Chandrasekhar, J.; Madura, J. D.; Impey, R. W.; Klein, M. L.; J. Comput. Phys. 1983, 79, 926.

29. Ramalho, T. C.; Taft, C. A.; J. Chem. Phys. 2005, 123, 054319.

30. Ramalho, T. C.; Caetano, M. S.; da Cunha, E. F. F.; J. Biomol. Struct. Dyn. 2009, 27, 195.

31. Ordentlich, A.; Barak, D.; Kronman, C.; Ariel, N.; Segall, Y.; Velan, B.; Shafferman, A.; J. Biol. Chem. 1996, 271, 11953.

32. Jorgensen, W. L.; Science 1991, 254, 954.

33. da Cunha, E. F. F.; Ramalho, T. C.; Mancini, D. T.; Fonseca, E. M. B.; Oliveira, A. A.; J. Braz. Chem. Soc. 2010, 21, 1787.

Submitted: March 6, 2011

Published online: July 19, 2011 